\title{
ANALISIS KADAR MERKURI (Hg) PADA BADAN AIR DI BEBERAPA TITIK SUNGAI WAIAPU KABUPATEN BURU
}

\author{
Abraham Mariwy', Yati Tuasamu², Warinah² \\ ${ }^{1}$ Program studi Pendidikan Kimia FKIP Universitas Pattimura Ambon \\ 2Program studi Pendidikan Kimia FKIP Universitas Darussalam Ambon \\ E-mail: abrahammariwy@gmail.com
}

Diterima 10 Mei 2019/Disetujui 12 Juni 2019

\begin{abstract}
ABSTRAK
Merkuri dan turunannya telah lama diketahui sangat beracun sehingga kehadirannya di lingkungan perairan dapat mengakibatkan kerugian pada manusia karena sifatnya yang mudah larut dan terikat dalam jaringan tubuh organisme air. Selain itu pencemaran merkuri mempunyai pengaruh terhadap ekosistem setempat yang disebabkan sifatnya yang stabil dalam sedimen, kelarutannya yang rendah dalam air dan kemudaahannya diserap dan terakumulasi dalam jaringan tubuh organisme air, baik melalui proses bioakumulasi maupun biomagnifikasi yaitu melalui rantai makanan. Penelitian ini dilakukan untuk menentukan kadar logam berat merkuri $(\mathrm{Hg})$ pada badan air dari sungai Waiapu Pulau Buru. Hal ini sangat penting dilakukan karena selama ini sungai tersebut menjadi tempat pembuangan limbah sisa pengolahan emas secara tradisional menggunakan tromol.Tahap penelitan lapangan meliputi pengukuran parameter fisika dan kimia serta pengambilan sampel dilakukan pada bulan Juli 2015. Sampel air sungai kemudian dikirim ke Laboratorium Kimia Universitas Muhamadiyah Malang untuk pengukuran kadar merkuri menggunakan AAS dengan teknik kurva kalibrasi. Hasil penelitian menunjukkan bahwa kadar merkuri pada tiga lokasi sampel yaitu $A B$ dan $C$ masing-masing adalah: 1,392 ppm, 1,5912 ppm dan 3,1975 ppm telah melampaui standar yang ditetapkan oleh pemerintah melalui keputusan Menteri Lingkungan Hidup RI Nomor 115 tahun 2003 yaitu ambang batas merkuri (Hg) pada air golongan $\mathrm{C}$ adalah $0,002 \mathrm{ppm}$.
\end{abstract}

Kata Kunci: merkuri, toksisitas, tromol, bioakumulasi, biomagnifikasi

\section{PENDAHULUAN}

Di Indonesia, pertambangan emas rakyat tersebar di berbagai daerah dan salah satu daerah yang menjadi fokus perhatian masyarakat pada beberapa tahun terakhir adalah tambang emas gunung Botak yang terletak di desa Wamsait Kecamatan Waelata Kabupaten Pulau Buru Provinsi Maluku. Pertambangan emas rakyat yang mulai beroperasi pada tahun 2011 tersebut telah menarik minat ribuan penambang dari berbagi daerah di Indonesia. Walaupun tambang emas di gunung Botak telah resmi ditutup pada akhir tahun 2015 berdasarkan instruksi Presiden, tetapi banyaknya jumlah penambang yang pernah beroperasi pada tambang tersebut yang semuanya menggunakan teknik amalgamasi dalam proses tersebut sangat berpotensi merusak lingkungan karena proses amalgamasi tersebut menggunakan merkuri $(\mathrm{Hg})$.

Pada proses amalgamasi yang dilakukan oleh para penambang secara tradisional, material tanah dan batuan yang mengandung emas dicampur dengan merkuri $(\mathrm{Hg})$ dengan media air dan diaduk menggunakan tromol (amalgamator). Teknik ini memanfaatkan putaran yang diberikan oleh tromol untuk menghancurkan tanah dan batuan yang masih bercampur dengan emas sehinga merkuri akan mengikat emas. Selanjutnya dilakukan pencucian dan pendulangan untuk memisahkan amalgam (campuran Au-Hg) dan ampas (tailing) (Cordi, dkk 2011). Proses amalgamasi seperti ini 
telah berlangsung sejak jaman Romawi dan masih digunakan hingga saat ini (Apleton, dkk 2009). Dalam prakteknya ampas (tailing) yang masih mengandung merkuri tersebut kemudian ditampung dalam bak penampung atau langsung dibuang ke sungai sehingga berpotensi mencemari badan air atau wilayah pertanian di sekitar daerah aliran sungai (DAS) tersebut.

Salah satu desa di sekitar gunung Botak yang menjadi tempat pengolahan emas secara amalgamasi adalah desa Waeleman yang terletak di dekat aliran sungai Waiapu pulau Buru. Penduduk desa ini mengolah emas menggunakan tromol pada rumah mereka masing-masing dan limbah dari proses tersebut langsung disalurkan ke sungai Waiapu tanpa melalui treatmen tertentu untuk mereduksi kandungan merkuri dari limbah tersebut padahal sungai terbesar di Pulau Buru ini dimanfaatkan oleh masyarakat untuk mengairi ratusan hektar sawah dan ladang.

Selain menjadi sumber irigasi untuk mengairi ratusa hektar lahan persawaan, sungai Waiapu bermuara di teluk Kayeli pulau Buru sehingga merkuri yang terbawa ke laut oleh aliran sungai tersebut berpotensi mencemari perairan di teluk Kayeli dan juga semua sumber daya perikanan di dalamnya. Sumber daya perikanan yang melimpah di teluk ini terdiri dari ikan pelagis besar seperti tuna, cakalang dan tongkol, ikan pelagis kecil seperti layang, kembung dan selar, ikan demersal seperti kerapu, pisang-pisang biji nangka dan ekor kuning. Teluk ini juga kaya dengan komoditas perikanan lainnya seperti udang windu, kepiting bakau, kepiting rajungan, teripang dan lobster serta kerang-kerangan (Haris, 2003).

Penelitian ini dilakukan untuk mengetahui konsentrasi merkuri $(\mathrm{Hg})$ pada badan air dari sungai Waiapu. Hal ini sangat penting dilakukan karena merkuri adalah logam berat yang sangat toksit dan keberadaanya dalam lingkungan perairan sangat berbahaya karena dapat meracuni manusia melalui rantai makanan.

\section{METODE PENELITIAN}

Alat-alat yang digunakan adalah AAS, beaker gelas, neraca analitik, Oven, hot plate, blender, peralatan gelas, cold box, thermometer dan $\mathrm{pH}$ meter Sementara bahan-bahan yang digunakan adalah: sampel air dari sungai Waiapu, Aquades, $10 \mathrm{~mL} \mathrm{HNO}_{3} 65 \%$, Kertas Saring, $10 \mathrm{~mL} \mathrm{KI}$, dithizone dan Larutan standar merkuri.

Tahap penelitian lapangan yang meliputi pengukuran suhu, $\mathrm{pH}$ dan pengambilan sampel air sungai dilakukan pada bulan Juni 2015. Sampel diambil pada tiga titik berbeda menggunakan metode purposive sampling yaitu menentukan lokasi sampling secara sengaja. Jarak anatar setiap titik pengambilan sampel adalah 100 meter dan pada setiap titik sampling dilakukan tiga kali pengambilan sampel sehingga total terdapat 9 sampel air sungai. Sampel tersebut kemudian diberi kode A, B dan C. Sampel diambil pada sore hari menggunakan botol sampel dan setelah dilakukan pengukuran suhu dan $\mathrm{pH}$ sampel kemudian disaring untuk memisahkan kotoran dan dimasukkan ke dalam kotak pendingin untuk proses selanjutnya di laboratorium.

\section{Preparasi Sampel}

Di laboratorium sampel air dipanaskan sampai suhu mencapai $70^{\circ} \mathrm{C}$, tambahkan $1 \mathrm{ml}$ larutan Kalium iodida $1 \%$ kemudian diamkan selama satu jam. Sampel kemudian disaring menggunakan kertas saring hingga di dapatkan residu selanjutnya residu dicuci menggunakan aquades. Larutkan endapan dalam larutan dithizone sebanyak $5 \mathrm{ml}$ kemudian homogenisasi dengan vorteks. Langkah selanjutnya adalah proses analisis menggunakan AAS.

\section{Pembuatan Larutan Standard}

Dari larutan induk $\mathrm{Hg} 1000$ ppm dipipet sebanyak $10 \mathrm{~mL}$, kemudian dimasukkan ke dalam tabung reaksi dan ditambahkan $10 \mathrm{~mL} \mathrm{HNO}_{3}$. Larutan tersebut kemudian dimasukkan ke dalam labu takar $100 \mathrm{~mL}$ dan diencerkan dengan aquadest hingga tanda batas. Larutan ini mengandung merkuri 100 ppm. Kemudian dari larutan ini dibuat seri larutan standar dengan konsentrasi 0, 5, 10, 20 dan 
25 ppm dengan cara memipet sebanyak $5,10,20$, dan $25 \mathrm{~mL}$ dan dimasukan ke dalam 4 buah labu takar bervolume $100 \mathrm{~mL}$ dan ditepatkan hingga tanda batas dengan aquades. Masing-masing larutan ini kemudian dianalisis menggunakan AAS.

\section{HASIL PENELITIAN}

\section{A. Hasil Pengukuran Parameter Fisika dan Kimia}

Hasil pengamatan parameter fisika dan kimia air sungai yang dilakukan selama penelitian memberikan gambaran mengenai kondisi sungai Waiapu pulau Buru. Hasil pengukuran parameter fisika dan kimia yang meliputi suhu dan $\mathrm{pH}$ dapat dilihat pada tabel 1.

Tabel 1. Hasil Pengukuran Suhu dan pH

\begin{tabular}{|c|c|c|}
\hline Nama Sampel & Suhu & pH \\
\hline Sampel. A & $28^{\circ} \mathrm{C}$ & 7 \\
\hline Sampel. B & $27^{\circ} \mathrm{C}$ & 7 \\
\hline Sampel. C & $26^{\circ} \mathrm{C}$ & 8 \\
\hline
\end{tabular}

Suhu merupakan salah satu faktor fisika yang sangat penting dalam lingkungan perairan. Perubahan Suhu perairan akan mempengaruhi proses fisika dan kimia perairan, demikian pula bagi biota perairan. Peningkatan Suhu dapat menyebabkan peningkatan kecepatan metabolisme dan respirasi biota air dan selanjutnya meningkatkan konsumsi oksigen. Berdasarkan hasil pengukuran yang dilakukan, suhu permukaan perairan sungai Waiapu berkisar antara $26-28{ }^{\circ} \mathrm{C}$, di mana Suhu terendah terletak pala lokasi sampel $\mathrm{C}$ dengan nilai $26^{\circ} \mathrm{C}$, sedangkan Suhu pada lokasi sampel $\mathrm{B}$ mencapai nilai $27^{\circ} \mathrm{C}$, sementara pada lokasi A Suhunya mencapai nilai $28{ }^{\circ} \mathrm{C}$. Kondisi suhu yang tinggi pada daerah lokasi sampel A terjadi diduga karena adanya aliran air yang deras, sehingga air lebih cepat panas di lokasi yang tidak terlalu dalam, tidak ada perbedaan Suhu yang cukup jauh antara lokasi sampel A, B, dan C, suhu tersebut relatif normal untuk perairan, apabila Suhu tinggi maka logam merkuri akan menguap ke udara sesuai dengan sifatnya yang mudah menguap, sehingga kadarnya dalam perairan akan menurun (Setiabudi, 2005).

Kisaran Suhu secara umum di perairan Indonesia berkisar $28-31^{\circ} \mathrm{C}$ kisaran Suhu yang dapat ditoleransi suatu biota perairan yaitu berkisar antara $20-35^{\circ} \mathrm{C}$ sedangkan berdasarkan Baku Mutu Kepmen LH No 51 tahun 2014 untuk biota perairan berkisar 28 - $31^{\circ} \mathrm{C}$. Berdasarkan hal tersebut, kisaran suhu permukaan air diperairan sungai waeapo selama pengamatan masih pada kisaran normal dan dapat ditoleransi oleh biota perairan (Sarjono,2009).

Derajat keasaman $(\mathrm{pH})$ adalah satu ukuran dari kosentrasi ion hidrogen dan menunjukan kondisi air, dengan mengetahui nilai $\mathrm{pH}$ perairan maka kita dapat mengontrol tipe dan laju kecepatan reaksi beberapa bahan dalam perairan. Nilai $\mathrm{pH}$ suatu perairan memiliki ciri yang khusus, adanya keseimbangan antara asam dan basa. Berdasarkanhasil pengukuran nilai $\mathrm{pH}$ perairan selama pengamatan di perairan sungai Waiapu menunjukkan nilai $\mathrm{pH}$ perairan basa dan cenderung stabil pada kisaran nilai 7 - 8. Nilai netral terletak pada lokasi sampel A dan B di mana pH nya mencapai nilai 7, sementara pada lokasi sampel $\mathrm{C}$ di mana nilai $\mathrm{pH}$ nya mencapai 8 . Berdasarkan kisaran nilai tersebut dapat disimpulkan bahwa, kondisi perairan sungai Waiapu masih tergolong baik menurut baku mutu keputusan Menteri Negara Lingkungan Hidup No 51 Tahun 2004 yang berkisar pada pH 7,0-8,5.

Pada lingkungan perairan, spesi merkuri tergantung dari kondisi reduksi-oksidasi dan kandungan bahan organik terlarut (DOC). Pada $\mathrm{pH}$ rendah, senyawaan merkuri dominan dalam bentuk $\mathrm{HgCl}_{2}$ dan $\mathrm{CH}_{3} \mathrm{Hg}^{+}$, sedangkan pada $\mathrm{pH}$ alkalis merkuri dominan dalam bentuk $\mathrm{Hg}^{\circ}$ dan $\left(\mathrm{CH}_{3}\right)_{2}$ $\mathrm{Hg}$ (Morel dkk, 1998, Boszke dkk, 2003 dalam Suseno, 2011). Pada air yang bersifat oksidatif senyawaan merkuri dominan dalam bentuk $\mathrm{HgCl}_{4}^{2-}$ dan $\mathrm{HgOH}^{+}$, sedangkan dalam kondisi reduktif 
senyawaan dalam bentuk $\mathrm{CH}_{3} \mathrm{HgS}$; dan $\mathrm{HgS}_{2}$. Di sisi lain dalam kondisi yang bervariasi senyawaan merkuri dominan terdapat dalam bentuk $\mathrm{CH}_{3} \mathrm{HgCl}$ dan $\mathrm{CH}_{3} \mathrm{Hg}^{2+}$.

\section{B. Kosentrasi Merkuri dalam Air}

Penelitian ini menggunakan teknik analisis kurva kalibrasi. di mana dari larutan induk $\mathrm{Hg} 1000$ ppm dipipet sebanyak $10 \mathrm{~mL}$ untuk membuat larutan merkuri $100 \mathrm{ppm}$. Dari larutan ini kemudian dibuat seri larutan standar dengan konsentrasi 0, 5, 10, 20 dan 25 ppm. Hasil pengukuran absorbansi larutan standar merkuri $(\mathrm{Hg})$ menggunakan AAS dapat dilihat pada Tabel 2 berikut

Tabel 2. Konsentrasi dan Absorbansi Larutan Standar Merkuri (Hg)

\begin{tabular}{|c|c|}
\hline $\begin{array}{c}\text { Konsentrasi } \\
\text { (mg/L) }\end{array}$ & Absorbansi \\
\hline 0 & 0 \\
\hline 5 & 0,031 \\
\hline 10 & 0,062 \\
\hline 20 & 0,121 \\
\hline 25 & 0,153 \\
\hline
\end{tabular}

Dari absorbansi yang diperoleh selanjutnya dibuat kurva kalibrasi antar konsentrasi dengan absorban. Kurva kalibrasi menyatakan hubungan antara berkas radiasi yang diabsorbsi $(\mathrm{A})$ dengan konsentrasi (C) dari zat standar yang telah diketahui konsentrasinya. Berdasarkan hokum LambertBeer absorbansi akan berbanding lurus dengan konsentrasi. Konsentrasi makin tinggi maka absorbansi yang dihasilkan makin tinggi. Kurva kalibrasi larutan standar merkuri $(\mathrm{Hg})$ dapat dilihat pada Gambar 1.

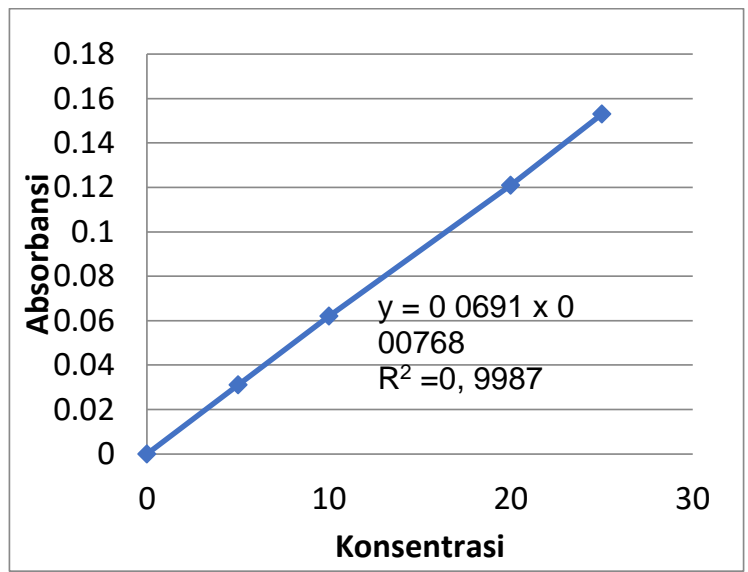

Gambar 1. Kurva standar Merkuri $(\mathrm{Hg})$

Berdasarkan pengukuran larutan standar, diperoleh persamaan linear $y=0,0691 x+0,00768$ dan nilai koefisien korelasi $\mathrm{R}^{2}=0,9987$. Gambar 1 menunjukkan bahwa kurva kalibrasi standar tersebut mempunyai garis singgung yang linear. Bentuk kurva tersebut mengikuti hukum Lambert Beer yaitu dengan meningkatnya konsentrasi maka absorbansi yang dihasilkan makin tinggi. Dari kurva nilai $R^{2}=0,9987$ yang diperoleh telah memenuhi syarat yang ditetapkan, dengan ketentuan 
$R^{2}>0$,99. Selanjutnya dilakukan pengukuran absorbansi larutan sampel, Konsentrasi dan absorbansi sampel digunakan untuk menghitung kadar Merkuri $(\mathrm{Hg})$ yang terdapat dalam sampel air sungai Waipu dengan mensubtitusikan persamaan linier kurva standar dan nilai koefisien $\mathrm{R}^{2}$. Konsentrasi merkuri pada sampel air sungai Waiapu ditunjukkan padaTabel 2.

Tabel 3. Konsentrasi Merkuri Pada Sampel

\begin{tabular}{|c|c|c|c|c|}
\hline Smpl & $\begin{array}{c}\text { Ulanga } \\
\mathbf{n}\end{array}$ & Abs & $\begin{array}{c}\text { Total } \\
\mathrm{Hg} \\
(\mathrm{mg} / \mathrm{L})\end{array}$ & $\begin{array}{l}\text { Rata- } \\
\text { rata }\end{array}$ \\
\hline \multirow[t]{2}{*}{$\mathrm{A} 1$} & 1 & 0,282 & 1,37 & \multirow[t]{2}{*}{1,3925} \\
\hline & 2 & 0,291 & 1,415 & \\
\hline \multirow[t]{2}{*}{$\mathrm{A} 2$} & 1 & 0,309 & 1,505 & \multirow[t]{2}{*}{1,5175} \\
\hline & 2 & 0,314 & 1,53 & \\
\hline \multirow[t]{2}{*}{ A3 } & 1 & 0,255 & 1,235 & \multirow{2}{*}{1,2975} \\
\hline & 2 & 0,28 & 1,36 & \\
\hline \multirow[t]{2}{*}{ B1 } & 1 & 0,423 & 1,0375 & \multirow{2}{*}{1,59125} \\
\hline & 2 & 0,437 & 2,145 & \\
\hline \multirow[t]{2}{*}{ B2 } & 1 & 0,462 & 2,27 & \multirow{2}{*}{1,2525} \\
\hline & 2 & 0,455 & 2,235 & \\
\hline \multirow[t]{2}{*}{ B3 } & 1 & 0,391 & 1,915 & \multirow{2}{*}{1,94} \\
\hline & 2 & 0,401 & 1,965 & \\
\hline \multirow[t]{2}{*}{ C1 } & 1 & 0,644 & 3,18 & \multirow{2}{*}{3,1975} \\
\hline & 2 & 0,651 & 3,215 & \\
\hline \multirow[t]{2}{*}{$\mathrm{C} 2$} & 1 & 0,618 & 3,05 & \multirow{2}{*}{3,06} \\
\hline & 2 & 0,622 & 3,07 & \\
\hline \multirow[t]{2}{*}{ C3 } & 1 & 0,637 & 3,145 & \multirow{2}{*}{3,16} \\
\hline & 2 & 0,643 & 3,175 & \\
\hline
\end{tabular}

Data hasil penelitian pada Tabel 3 menunjukkan bahwa rata-rata kandungan logam berat merkuri tertinggi terdapat pada lokasi sampel C yang mencapai 3,13917 ppm. Tingginya kandungan logam berat merkuri ini disebabkan oleh adanya aktivitas penambangan emas tradisonal oleh penduduk desa Waeleman yang berada di tepi Sungai Waipau menggunakan tromol. Dalam prakteknya para penambang tradisional ini membuang limbah hasil penegolahan emas ini langsung ke badan air sehingga berdampak pada tingginya konsentrasi merkuri pada lokasi tersebut. Tingginya konsentrasi merkuri pada lokasi $\mathrm{C}$ disebabkan juga karena aliran sungai yang melewati lokasi sampel A dan B sehingga konsentrasi logam berat merkuri menumpuk pada lokasi sampel C.

Sementara rata-rata kandungan logam berat merkuri terendah terdapat pada lokasi sampel $A$ yaitu 1,4025 ppm, meskipun lokasi sampel A berdekatan dengan desa Waeleman dan banyak terdapat tromol namun aliran sungai yang melewati lokasi ini cukup deras sehingga logam berat Merkuri yang berada di badan air lansung terbawa arus sungai dan tertumpuk pada lokasi $C$ yang arus sungainya tidak terlalu deras. Sedangkan pada pada lokasi sampel B, kandungan Merkurinya mencapai $1,92792 \mathrm{ppm}$. Sama halnya dengan lokasi sampel A, aliran sungai memungkinkan berkurangnya konsentrasi merkuri sehingga partikel merkuri dalam air ataupun sedimen akan bergerak mengikuti arus ke arah hilir dan selanjutnya mengendap di muara sungai ataupun teluk Kayeli tempat sungai Waiapu bermuara. Selanjutnya konsentrasi logam berat merkuri pada setiap lokasi sampling dapat dilihat pada Gambar 2 berkut. 


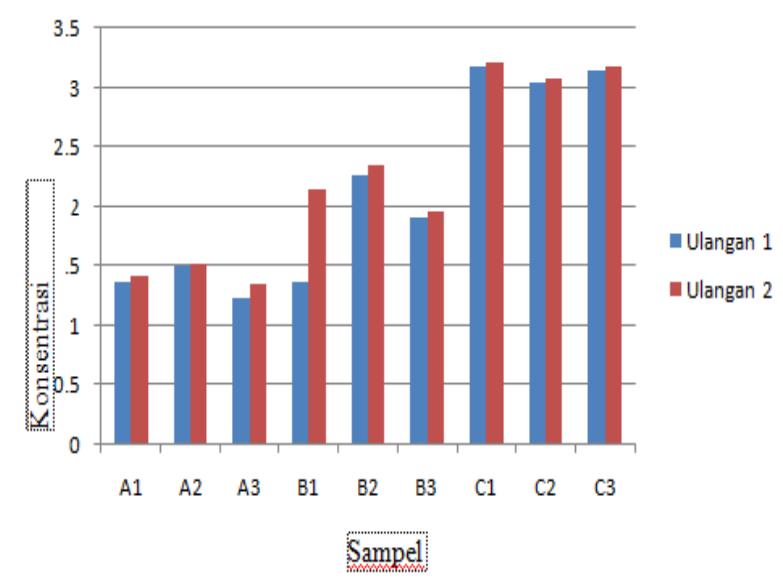

Gambar 2. Diagram konsentrasi Merkuri (Hg) Pada Setiap Lokasi Sampling

Keberadaan logam berat merkuri dalam badan air sungai Waipu sangat berbahaya karena bila musim hujan tiba, sungai terbesar di pulau Buru ini akan meluap sehingga menggenangi puluhan hektar area persawahan yang berada di sekitar sungai tersebut. merkuri yang terbawa air ke dalam lahan persawahan kemudian akan mengendap di dalam tanah selanjutnya secara alami unsur-unsur tersebut akan terserap dan masuk ke dalam jaringan tanaman padi bersama-sama dengan unsur hara dan air yang dibutuhkan untuk fotosintesis. Beras yang dikonsumsi manusia dari tanaman padi yang terkontaminasi merkuri dan logam berat lainnya dipastikan akan berdampak serius pada kesehatan (Badan penelitian dan pengembangan pertanian, 2004).

Selain dapat mencemari lahan persawahan, sungai Waiapu bermuara di teluk Kayeli pulau Buru sehingga dapat mencemari perairan di teluk Kayeli dan juga semua sumber daya perikanan di dalamnya. Hal ini terjadi karena merkuri $\mathrm{Hg}^{2+}$ yang dihasilkan dari perombakan senyawa merkuri pada endapan lumpur (sedimen), dengan bantuan bakteri akan berubah menjadi dimetil merkuri $\left(\mathrm{CH}_{3}\right)_{2} \mathrm{Hg}$ dan ion metil merkuri $\left(\mathrm{CH}_{3} \mathrm{Hg}^{+}\right)$. Ion metil merkuri mudah menguap ke udara dan oleh faktor fisika di udara senyawa dimetil merkuri akan terurai kembali menjadi metana $\mathrm{CH}_{4}$, etana $\mathrm{C}_{2} \mathrm{H}_{6}$ dan logam $\mathrm{Hg}^{\circ}$. Sementara itu ion metil merkuri mudah larut dalam air dan dimakan ole biota perairan, organisme kecil ini membawa metil merkuri kepada hewan yang memangsa mereka. Proses ini dikenal sebagai bioakumulasi dan akan terus berlanjut dengan kadar merkuri yang semakin meningkat. Hewan pemangsa seperti ikan memiliki posisi tertinggi dalam mata rantai pembawa merkuri, dan manusia yang mengkomsumsi ikan seperi ini akan terpapar oleh merkuri (Lousiana Departement of Health \& Hospital, 2008)

Ikan yang merupakan salah satu predator puncak ekosistem perairan, mengakumulasi $\mathrm{CH}_{3} \mathrm{Hg}^{+}$ dan $\mathrm{Hg}^{2+}$ dari berbagai jalur paparan yaitu: air, makanan dan partikulat (Suseno, 2011). Berbagai hasil penelitian menunjukkan bahwa senyawan merkuri yang terkandung dalam daging ikan sebanyak 80 $90 \%$ berbentuk $\mathrm{CH}_{3} \mathrm{Hg}^{+} \cdot \mathrm{Hal}$ ini tentu saja sangat berbahaya karena ikan banyak dikonsumsi oleh masyarakat sehingga menjadi sumber utama asupan $\mathrm{CH}_{3} \mathrm{Hg}^{+}$pada manusia (Schwindt, dkk 2009 dan Suseno, 2011). Jenis-jenis ikan di teluk Kayeli terdiri dari ikan pelagis besar seperti tuna, cakalang dan tongkol, ikan pelagis kecil seperti layang, kembung dan selar, ikan demersal seperti kerapu, pisang-pisang biji nangka dan ekor kuning. Teluk ini juga kaya dengan komoditas perikanan lainnya seperti udang windu, kepiting bakau, kepiting rajungan, teripang dan lobsterserta kerangkerangan (Haris, 2003).

Hasil penelitian ini menunjukkan bahwa kadar merkuri pada badan air sungai Waiapu telah jauh melampaui standar yang ditetapkan ole pemerintah Indonesia seperti tercantum dalam Keputusan 
Menteri Negara Lingkungan Hidup RI Nomor 115 tahun 2003 yang mensyaratkan ambang batas logam berat merkuri $(\mathrm{Hg})$ dalam air golongan $\mathrm{C}$ adalah $0,002 \mathrm{ppm}$.

\section{KESIMPULAN}

Hasil penelitian ini menunjukkan bahwa rata-rata kadar merkuri di tiga lokasi sampel pada badan air sungai Waiapu yaitu A B dan C masing-masing adalah: 1,392 ppm, 1,5912 ppm dan 3,1975 ppm. Konsentrasi logam berat merkuri pada ketiga sampel telah jauh melampaui standar yang ditetapkan oleh pemerintah melalui keputusan Menteri Lingkungan Hidup RI Nomor 115 tahun 2003 yaitu ambang batas merkuri $(\mathrm{Hg})$ pada air golongan $\mathrm{C}$ adalah 0,002 ppm. Hal ini tentu sangat mengkhawatirkan karena bila tiba musim hujan, sungai ini sering meluap dan menggenangi puluhan hektar area persawahan yang berada di sekitarnya sehingga dapat menimbullkan masalah kesehatan bagi masyarakat yang mnegkonsumsi beras dari areal persawahan tersebut. Selain itu, sungai Waiapu bermuara di teluk Kayeli sehingga merkuri yang terbawa oleh aliran sungai ini berpotensi mencemari teluk Kayeli beserta semua sumber daya perikanan di dalamnya.

\section{DAFTAR PUSTAKA}

Appleton J.D, Wiliams T.M, Breward.N, Apostol. A, Miguel.J, Miranda.C 1999. Mercury contamination associated with artisanal gold mining on the island of Mindanao, the Philippines. The science of the total environment 228. 95-109.

Badan Penelitian dan Pengembangan Pertanian, 2004. Tanah Sawah dan teknologi Pengelolahannya, Bogor

Cordi. P, Veiga M.M, Salih I, Al-Saadi S, Console S, Garcia O, Mesa L.A, Velasquez-Lopez P.C, Roeser M 2011, Mercury contamination from artisanal gold mining in Antioquia, Columbia: The worlds highest per capita mercury pollution. Science of the total Environment 410411, 154-280

Haris, A. 2003, Analisis kesesuaian lahan dan kebijakan pemanfaatan ruang wilayah pesisir teluk kayeli pulau Buru, Tesis IPB Bogor

Keputusan Menteri Negara Lingkungan Hidup nomor 115 tahun 2003, tentang kriteria baku mutu perairan

Keputusan Menteri Negara Lingkungan Hidup nomor 51 tahun 2004, tentang kriteria baku mutu perairan

Lousiana Departement of Health \& Hospitals 2008, Information for healt care professionals mercury eksposure and toxicity

Sarjono, Arya. 2009. Analisis kandungan logam berat $\mathrm{Hg}$, Cd, dan Pb. Pada air dan sedimen di perairan kamal muara jakarta utara (skripsi) Bogor. Fakultas Perikanan Dan IImu Kelautan Institut Pertanian Bogor

Setiabudi, B. T. 2005. Penyebaran merkuri akibat usaha pertambangan emas di daerah sangon kabupaten kulon progo. Yokyakarta. Subdit Konservasi.

Suseno Heni 2011, Bioakumulasi Merkuri dan metil merkuri oleh Oreochromis Mossambicus Menggunakan Aplikasi Perunut Radioaktif: Pengaruh Konsentrasi, salinitas, partikulat ukuran ikan dan Kontribusi Jalur pakan). Disertasi UI Depok

Schwindt R.A 2009, Mercury Concentration in Salmonids from Weterns U.S. National Parks and Relationships With Age and Macrophage Aggregates . Environ. Sci. Technol.2, 1365-137 